\title{
Statyba
}

\section{RISK ANALYSIS IN THE INVESTMENTS OF CONSTRUCTION PROJECTS}

\section{R. Tamošiūnienè}

To cite this article: R. Tamošiūnienè (1999) RISK ANALYSIS IN THE INVESTMENTS OF CONSTRUCTION PROJECTS, Statyba, 5:1, 59-67, DOI: 10.1080/13921525.1999.10531434

To link to this article: https://doi.org/10.1080/13921525.1999.10531434

册 Published online: 26 Jul 2012.

Submit your article to this journal $₫$

Џ Article views: 243

7 Citing articles: 1 View citing articles 


\section{RIZIKOS ANALIZĖS REIKŠMĖ STATYBOS INVESTICINIAMS PROJEKTAMS}

\section{R. Tamošiūnienè}

\section{1. İvadas}

İmonès funkcionavimas šiandienos sąlygomis neišvengiamai susijęs su rizika - dèl atliekamy darbų būsimų sąlygų neapibrežtumo ir del galimų klaidingų sprendimų, kuriuos gali priimti įmonès vadovai.

Rizikai (įvairioms jos rūšims), jos ịvertinimui, prognozavimui ir valdymui kol kas per mažai dèmesio skiria tiek verslininkai, tiek ir valstybès institucijos, susijusios su verslo plètra. Deja, daugelio Lietuvoje igyvendinamų verslo projektų rizikos lygis yra gerokai didesnis nei atitinkamų verslo projektų, iggvendinamų išsivysčiusiose užsienio šalyse. Dauguma užsienio investuotoju labai daug demesio skiria priešinvesticinei projekto fazei, kurios metu, be techninès, komercinès, ekologinès, socialinès, institucinès, finansinès ir ekonominès analizès, atliekama ir rizikos analizè.

Klausimai, susiję su rizika imonès veikloje (arba igyvendinamame investiciniame projekte), domina ne tik įmonès darbuotojus, bet ir jos akcininkus, investuotojus, tiekèjus, vartotojus. Taigi jei atliekant investicinio projekto analizę (apimančią minètas analizès rūšis) arba sudarant įmonès verslo planą rizikos analizei skiriama per mažai dèmesio, tai projekto dalyviams (tiekejams, investuotojams, vartotojams ir pan.) tai gali būti ženklas, kad projekto dokumentacija parengta netinkamai ar kad ją parengusių darbuotoju kompetencija yra nepakankama.

Visi verslo projekto dalyviai nori, kad jų sumanytas ir igyvendinamas projektas nesužlugtu arba būty nenuostolingas bent jau jiems patiems. Todèl verslo projekto stadijoje, norint sumažinti nuostolius arba netgi išvengti projekto žlugimo dèl kokių nors klaidy ar nenumatytu atvejų, reikia taikyti projekto valdymo metodologiją, kurioje numatomos specialios procedūros, leidžiančios ịvertinti daugumą rizikos ir neapibrěžtumo veiksniu visuose projekto etapuose ir fazèse [1] ir [2].
Šio straipsnio tikslas - pateikti ivvairiu rizikos rūšị klasifikaciją, nurodyti tinkamiausią klasifikaciją statybinio pobūdžio investiciniams projektams ir pasiūlyti rizikos analizés metodiką bei rizikos valdymo modelį, adekvačiai tinkančius investiciniams statybos projektams.

Tyrimas buvo atliekamas, remiantis bendraisiais moksliniais metodais: analize ir sinteze, analogija ir modeliavimu, konkretinimu ir sistemine analize.

\section{Svarbiausios sąvokos ir apibrèžimai}

Neapibrēžtumas suprantamas kaip nepakankama ir netiksli informacija apie projekto realizavimo sąlygas ir su tuo susijusios išlaidos ir nauda (rezultatai).

Neapibrežtumas, susijęs su galinčiomis atsirasti projekto eigoje nepalankiomis situacijomis ir pasekmèmis, apibrèžiamas rizikos sąvoka [2], [3].

M. Volkovas ir M. V. Gračiova [4] riziką apibūdina kaip potencialią, kiekybiškai įvertinamą nuostolių galimybę. Neapibréžtumas, pagal šiuos autorius, numato veiksnius, kuriems egzistuojant veiklos rezultatai yra nedeterminuoti, o šį veiksniu galimos įtakos dydis nežinomas. Kitaip sakant, neapibrěžtumą lemia netiksli arba nepakankama informacija, dèl to projekto eigoje gali atsirasti nenumatytų ir neịvertintų situacijų.

Dažniausiai šios dvi sąvokos (rizika ir neapibrèžtumas) analizèje, beje, ir praktinèje veikloje, vartojamos kartu.

Labai svarbi yra rizikos valdymo sąvoka. V.D. Šapiro [2] šią sąvoką ịvardija kaip visumą priemonių ir metodų, kuriais remiantis atrenkami ir ịvertinami pagal jụ svarbumą visi rizikos veiksniai, sumodeliuojamas projekto realizavimo procesas, įvertinama nepalankiu situacijų ir jų pasekmių atsiradimo tikimybé, parenkami metodai jy poveikiui sumažinti, kontroliuojami bei koreguojami faktiniai projekto parametrai jo igyvendinimo eigoje. 
Taip pat labai svarbią reikšmę atliekant projektinę analizę turi įvairių rizikos rüšił konkrečiame projekte indentifikavimas. Tam tikslui projekto analitikas turi turèti išsamią rizikos rūšių klasifikaciją.

Žemiau pateikiama keletas rizikos klasifikacijos pavyzdžiu.

Pagal V. D. Šapiro [2] ǐsskiriamos tokios rizikos rūšys:

\section{- Išorine nenumatoma rizika:}

1. Nenumatytos (nelauktos) valstybés reguliavimo priemonés tokiose sferose, kaip materialinis-techninis tiekimas, gamtos apsauga, eksportas ir importas, mokesčių mokejjimas ir pan.

2. Gamtos stichija.

3. Nenumatyti išoriniai veiksniai (ekologiniai, socialiniai).

4. Sužlugdymas (dèl būtinos infrastruktūros nebuvimo, dèl tiekejjų, subrangovų bankroto ir pan.).

- Išoriné numatoma (bet neapibrěžta) rizika:

1. Rinkos rizika (sunkiau gauti žaliavų, jų kainos padidejimas, vartotojų poreikių pasikeitimas ir pan.).

2. Gamybos proceso veiksniai (nèra galimybių darbo jegos kvalifikaciniam lygiui palaikyti, darbo saugumo pažeidimai ir pan.).

3. Neleistinas ekologinis poveikis.

4. Neigiamos socialinès pasekmès.

5. Valiutų kurso pasikeitimas, infliacija ir kt.

- Vidine netechnine rizika:

1. Suplanuoty darbu sužlugdymas dél darbo jègos trūkumo, medžiagų trūkumo, pavèluoto jų pristatymo, projekto klaidų, planavimo klaidų ir pan.

2. Išteklių pereikvojimas dèl darbo planų sužlugdymo, neteisingai apskaičiuotų sąmatų, netinkamos tiekimo strategijos ir pan.

- Technine rizika:

1. Technologijos pasikeitimas.

2. Gamybos, susijusios su projektu, kokybès ir darbo pajègumo pablogèjimas.

3. Specifinès technologijos, diegiamos i projektą, rizika.

4. Projektavimo dokumentu ir sąmatų netikslumas.

- Teisiné (juridinè) rizika:

1. Licencijos, patento teisè.
2. Kontraktų nevykdymas, vidiniai ir išoriniai teisiniai procesai.

3. Fors-mažorinès (nepaprastosios) aplinkybès.

- Apdraustoji rizika:

1. Tiesioginiai nuosavybès nuostoliai dèl transporto incidentų ir pan.

2. Netiesioginiai nuostoliai dél ịrengimu perstatymo, suplanuoto veiklos ritmo pažeidimo ir t.t.

3. Rizika, kurią apdraudžia pašaliniai asmenys pagal atitinkamą normatyvinę dokumentaciją.

Čia pateikta beveik visų rizikos rūšių, su kuriomis galima susidurti igyvendinant projektą, klasifikacija.

V. Z. Černiakas, aprašydamas investiciniu statybos projektų valdymą [5], išskiria tokias rizikos rūšis, kaip statybinę, kontraktinę, fizinę, vykdomają ir vadybinę, ekonominę ir politinę ir sujungia jas $\mathfrak{i}$ vieną - bendrają riziką.

Autorés nuomone, netgi investiciniuose statybos projektuose, norint identifikuoti visas rizikos rūšis, geriau remtis išsamesne V. D. Šapiro pateikta rizikos klasifikacija. Kadangi šioje klasifikacijoje rizika skirstoma į išorinę ir vidinę, tai leidžia projekto analitikui, ivertinančiam statybos investicinio projekto rizikingumą, atsižvelgti ne tik $\mathfrak{i}$ paties projekto, bet ir i jo aplinkos ypatumus.

Statybos investiciniuose projektuose galima būtų išskirti šiuos (kritinius) rizikos veiksnius:

- projektavimo dokumentų ir sąmatu klaidos;

- specialistų kvalifikacijos neatitikimas;

- fors-mažorinès aplinkybès;

- kainų nustatymo aplinkybès;

- tiekimu užlaikymas;

- prasta medžiagu, gaminių bei technologiniu procesu kokybe்;

- kontrakto nutraukimas.

Analitikai paprastai išskiria dvi rizikos grupes:

- dinamiškoji - tai nenumatyty pasikeitimu rizika projekto vertinèje išraiškoje dèl pirminių valdymo užduočiu pasikeitimo. Tokie pasikeitimai gali sąlygoti tiek nuostolius, tiek papildomas išlaidas;

- statiškoji - tai realaus turto praradimo rizika dèl padarytos žalos nuosavybei arba dèl netinkamos organizacijos. Ši rizika gali atnešti tik nuostolių [2]. 
Norint nustatyti, kaip būty̨ galima sumažinti riziką, jos neigiamą ịtaką projektui, pirmiausia reikia išsiaiškinti įvairiausius rizikos veiksnius ir ịvertinti ju reikšmingumą, t. y. reikia atlikti rizikos analizę [1].

Rizikos analizés tikslas - potencialiems projekto partneriams pateikti būtinus duomenis, kad jie galètụ priimti sprendimus dèl dalyvavimo projekte tikslingumo ir dèl metody̨, apsaugančių nuo galimų finansinių nuostolių, parinkimo [2]. Iš to seka, kad rizikos analizę turi atlikti visi projekto dalyviai:

- Užsakovas analizès rezultatus panaudoja visiems projekto elementams planuoti: galima teigti, kad jis yra viena iš labiausiai suinteresuotų projekto šalių.

- Rangovas stengiasi nustatyti ir apriboti kieki ir "kainą" rizikos veiksniy, už kuriuos jis turèty atsakyti. Be to, analizès rezultatai jam gali padéti suformuoti realesni veiksmy planą, neperžengiant projekto rémų.

- Bankas, pasinaudodamas analize, nustato atitinkamas projekto kreditavimo sąlygas.

- Draudimo kompanija, remdamasi analizès duomenimis, numato pagrịstą projekto dalyvių turto arba kitokị draudimą.

Reikia pažymèti, kad Lietuvoje pastaruoju metu rizikos analizès atlikimo tvarkai verslo planuose arba projektuose gerokai didesnị dèmesį skiria bankai. Pavyzdžiui, Lietuvos žemès ūkio banko "Nurodymuose verslo plano paruošimui" 9-ame punkte ("Kreditavimo vadovas") reikalaujama iš imonès atlikti jautrumo ir rizikos analizę ir nurodyti svarbiausius rizikos, susijusios su finansuotinu verslu, veiksnius.

Rizikos analizei atlikti dažniausiai taikomas analogiju metodas arba statistinis metodas [2]. Taikant analogijy metodą naudojami duomenys apie kitus, anksčiau igyvendintus projektus. Užsienyje analogijų metodą dažniausiai taiko draudimo kompanijos. Lietuvoje šis metodas, deja, néra labai paplitęs dẻl kelių priežasčių: valdymas pagal projektus - gana nauja valdymo forma, todèl dar nèra pakankamai jau igyvendintų investicinių projektų, iš kurių bũtų galima pasisemti patirties. Be to, dažnai verslo imonés yra linkusios slépti savo tikrąją padèti, o juo labiau dalintis patirtimi su naujai pradedančiais verslininkais.
Autorès nuomone, analogijų metodas galètų būti plačiau taikomas, ivvertinant statybos investicinių projektų riziką (ypač pirminiu jos vertinimo etapu). Jeigu statybos firma ruošiasi realizuoti projektą, kuris yra analogiškas jau igyvendintiems projektams, tai, remiantis "turima statistine medžiaga, galima nubrèžti vadinamają rizikos kreivę" [4]. Tačiau, norint sèkmingai pritaikyti ši metodą, reikia, kad informacijos bankas būtų išsamus ir patikimas.

Pastaruoju metu vis dažniau taikomas, ypač dideliems projektams, statistinių bandymy metodas, t. y. Monte-Karlo metodas. Šio metodo taikymas yra gana sudetingas ir be kompiuterizuotos programos neįmanomas. Vieną iš tokių programiniu paketu "Risk-Master" - yra parengęs Harvardo universitetas [4]. Trečiojoje šio darbo dalyje yra pateikta paprastesnè minèto metodo taikymo schema (1 pav.).

Prieš pradedant nagrinèti rizikos analizès metodiką, reikia paminèti, kad rizikos analizę galima išskirti $\mathfrak{i}$ dvi viena kitą papildančias grupes: kokybinę ir kiekybinę.

Kokybine analize identifikuojami rizikos veiksniai, jos veikimo sritys ir rūšys. Kiekybinès analizès metu kiekybiškai ịvertinami atskirų riziku dydžiai ir bendras viso projekto rizikingumas [2]. Kitame literatūros šaltinyje [4] pateikiama išsamesnè ir, mano nuomone, tikslesnè šių dvieju rizikos analizès pakraipu paskirtis. Čia nurodoma, kad svarbiausia kokybinès analizès savybé yra ta, kad ją atlikus yra ne tik identifikuojamos visos nagrinejamo projekto rizikos rūšys, nurodomos galimos ju atsiradimo priežastys ir numatomos jų realizavimo pasekmès, jų minimizavimo arba kompensavimo priemones, bet ir atliekamas vertinis pasekmių bei visu riziką minimizuojančiu ir kompensuojančių priemonių apskaičiavimas. Prie kokybinès rizikos analizès rezultatų galima priskirti ir galimy visu projekto veiksniu (kintamuju), tikrinant ju rizikingumą, ribinių (kraštinių) reikšmių nustatymą. Kaip matome, kokybinès analizès metu nustatomi visi projekto veiksniai (kintamieji), kurių rizikingumas gali būti patikrintas.

Kiekybinès analizès užduotis - "rizikingų veiksnių pokyčiu itakos projekto efektyvumui kiekybinis ivertinimas" [4]. Kiekybinė analizè dažniausiai atliekama remiantis šiais metodais: jautrumo analize, scenarijy analize ir imitaciniu riziku modeliavimu pagal Monte-Karlo metodą. 


\section{Rizikos ir neapibrèžtumo analizẻs metodai}

Pastaruoju metu investiciniu projektu projektinès rizikos analizès praktikoje taikomi gana ivvairūs metodai priklausomai nuo projekto sudètingumo, jo mastu ir nuo investuotoju bei kitu projekto dalyviu požiūrio ị riziką ir neapibrèžtumą.

Pradiniame etape dažniausiai taikomas ekspertinių vertinimy metodas. Tolesniame (kiekybiniame) vertinimo etape taikomi metodai, kuriuose naudojami dispersijos ir vidutinio kvadratinio nuokrypio rodikliai, leidžiantys kiekybiškai ịvertinti keliu projektų (arba kelių vieno projekto variantu) rizika. Tais atvejais, kai projektas turi kelias išeities pozicijas, dispersija charakterizuoja atsitiktinès reikšmès (dažniausiai grynosios dabartinès vertès (NPV)) išsibarstymo lygi apie savo vidutinę reikšmę (matematinę viltị).

Toliau darbe yra išnagrineta keletas kiekybinių ir kokybinių rizikos analizès metodų, adekvačiai tinkančių statybos investiciniams projektams.

Finansinę riziką investiciniuose statybos projektuose V. Z. Černiakas [5] siūlo vertinti remiantis tokiais rodikliais, kaip suvidurkintas apskaitinis pelningumo lygis, dabartinès vertès indeksas, vidutiné svertinè kapitalo kaina.

Suvidurkintas apskaitinis pelningumo lygis apskaičiuojamas pagal formulę:

$$
S A P L=\frac{\sum_{j=1}^{n} G P(n)}{n},
$$

kur $\sum G P(n)$ - grynasis pelnas kiekvienais atsiskaitomojo periodo metais; $n$ - atsiskaitomuju periody skaičius.

Pastaba. Vietoj grynojo pelno rodiklio gali būti imama grynoji dabartinè vertè.

Dabartinès vertès indeksas apskaičiuojamas pagal formulę:

$$
D V I=\frac{\sum_{j=1}^{n} G P(n) \times\left(1+a_{0}\right)^{-t_{i}}}{n},
$$

kur $\left(1+a_{0}\right)^{-t_{i}}$ - i-ojo periodo diskontavimo koeficientas.

Akivaizdu, kad SAPL > DVI.

Vidutinè svertinè kapitalo kaina apskaičiuojama tokiu nuoseklumu:
1) Pirmiausia nustatomas skolinamojo ir nuosavo kapitalo santykis (SK/NK).

2) Iš bendro kapitalo išskiriama nuosavu lèšu dalis, kurią sudaro įstatinis kapitalas, investicijos, skirtos inovaciniams projektams idiegti, dividendy mokejjimas. Svarbiausias šaltinis investavimui ir dividendų mokejjimui čia yra grynasis pelnas.

3) Nustatoma skolos kaina pagal šią formulę, ivertinus pelno mokesti:

$$
S K=i \times(1-t),
$$

kur $i$ - skolinamojo kapitalo palūkanụ norma, $t$ pelno mokestis, $\%$.

4) Vidutinè svertinè kapitalo kaina apskaičiuojama pagal formulę:

$$
V S K K=S K \times t+N K \times(1-t) .
$$

Vidutinè svertiné kapitalo kaina parodo tokią procentinę normos reikšmę, pagal kurią galima būtų atsiskaityti ir su kreditoriais, ir su nuosavos kompanijos savininkais.

Kad finansinè rizika neturetu didesnès įtakos projektui (įmonei), reikia, kad IRR (vidinè pelno norma) būtu didesnè už vidutinę svertinę kapitalo kainą, kuri yra jau pakoreguota ivertinus riziką, o grynoji dabartinè verté turi būti teigiama (NPV>0).

Kitas rizikos ir neapibrèžtumo ịtakos sumažinimo būdas investiciniuose projektuose gali būti projekto parametrų, naudojamy skaičiuojant ekonominius normatyvus, koregavimas [2].

Pavyzdžiui, statybos trukmè gali būti padidinta vidutiniu galimų uždelsimų dydžiu, arba gali būti padidinta statybos darbų vertè dẻl padarytu projektavimo klaidų, dèl nenumatytų išlaidu ir kiţ priežasčių. Reikètų atsižvelgti ir ił mokẻjimų uždelsimą, neritmingą medžiagu ir žaliavu pristatymą, technologines klaidas, sutarties įsipareigojimy̨ nevykdymą ir pan.

Tuo atveju, jeigu projekto dalyvis (rangovas ar kiti) nèra apdraustas nuo minètos rizikos, jis turèty i savo sąnaudas įtraukti ir laukiamus nuostolius dèl rizikos.

Vienas iš labiausiai paplitusių kiekybinés analizès metody yra jautrumo analizè. Jos tikslas - išryškinti kritinius projektui veiksnius (kintamuosius) bei patikrinti kiekvieno iš ju nuosekliu pasikeitimy ịtaką projekto rezultatams. Jautrumo analizé, kaip viena iš kie- 
kybinès analizès formų, atliekama remiantis prieš tai atliktais kokybinès analizès rezultatais [2], [4]. Atliekant jautrumo analizę, kintamaisiais veiksniais gali būti infliacijos rodikliai, fizinè pardavimy apimtis, kintamosios išlaidos, reikalinga investicijų apimtis ir kiti [1]. Šie kintamieji gali būti suskirstyti ị dvi grupes [4]:

1) veiksniai, turintys įtakos pajamų, gaunamų iš projekto, kiekiui;

2) veiksniai, turintys įtakos projektinių sąnaudy kiekiui.

Vienas iš paprasčiausiu būdụ ìvertinti projekto riziką pagal jautrumo analizès metodą - nenuostolingumo taško analizè. Kitu būdu jautrumo analizę galima atlikti, taikant matematinio programavimo metodus [4], [6].

Ekonominè-matematinè jautrumo analizès esmè ta, kad, remiantis baziniu projekto variantu, apskaičiuojamas laukiamas kiekvieno kintamojo veiksnio vidutinis nuokrypis bei projekto rezultatai, ịvertinant vieno kintamojo nuokrypio nuo bazinio varianto itaką [4]. Atliekant jautrumo analizę, uždavinio sprendinio tikslas dažniausiai būna nagrinèjamo projekto parametrų neigiamų pokyčių ribinių reikšmių apskaičiavimas tam, kad projektas išliktų pelningas.

1 lentelè. Projekto veiksnių, tikrinant jų rizikingumą, reitingo nustatymas

Table 1. Determination of project factors due to risk

\begin{tabular}{|c|c|c|c|c|c|}
\hline $\begin{array}{c}\text { Kinta- } \\
\text { masis } \\
\mathbf{x}\end{array}$ & $\begin{array}{c}\text { Veiksnio } \\
\text { pokytis } \Delta \mathrm{x}, \\
\%\end{array}$ & $\begin{array}{c}\text { Nauja } \\
\text { NPV } \\
\text { reikšmé }\end{array}$ & $\begin{array}{c}\Delta \mathrm{NPV}, \\
\%\end{array}$ & $\begin{array}{c}\text { NPV } \\
\text { elastin- } \\
\text { gumas } \\
\left(\begin{array}{c}\Delta \mathrm{NPV} / \\
\Delta \mathrm{x})\end{array}\right.\end{array}$ & $\begin{array}{c}\text { Projekto } \\
\text { veiksniu } \\
\text { reitingas }\end{array}$ \\
\hline & & & & & \\
\hline
\end{tabular}

Pastaba. Projekto veiksniy reitingas nustatomas, remiantis NPV elastingumo reikšme.

2 lentelè. Projekto kintamujų prognozavimo ir jautrumo rodikliai

Table 2. Forecasting and sensitivity indexes of project variables

\begin{tabular}{|c|c|c|c|c|}
\hline $\begin{array}{c}\text { Kinta- } \\
\text { masis }\end{array}$ & $\begin{array}{c}\text { NPV } \\
\text { elastin- } \\
\text { gumas }\end{array}$ & $\begin{array}{c}\text { Jautrumas } \\
\text { (reikšmin- } \\
\text { gumas) }\end{array}$ & $\begin{array}{c}\text { Progno- } \\
\text { zavimo } \\
\text { galimumas }\end{array}$ & $\begin{array}{c}\text { Kritinè } \\
\text { reikšme }\end{array}$ \\
\hline & & & & \\
\hline
\end{tabular}

Pastaba. Jautrumas gali būti didelis, vidutinis, mažas; prognozavimo galimumas atitinkamai - mažas, vidutinis, didelis.
3 lentelé. Prognozavimo ir jautrumo matrica

Table 3. Matrix of forecasting and sensitivity

\begin{tabular}{|c|c|c|c|}
\hline $\begin{array}{c}\text { Kintamujuc } \\
\text { prognozavimas }\end{array}$ & \multicolumn{3}{|c|}{ Kintamojo jautrumas } \\
\hline & Didelis & Vidutinis & Mažas \\
\hline Mažas & I & I & II \\
\hline Vidutinis & I & II & III \\
\hline Didelis & II & III & III \\
\hline
\end{tabular}

Pastaba. I - reikia tolesnio patikrinimo; II - toliau atidžiai stebimas; III - nustatomas ir užmirštamas.

Formalizuotą investicinio projekto jautrumo analizès procedūrą galima pavaizduoti lentelèmis $(1,2,3$ lent.). Jos parengtos remiantis literatūros šaltiniais [7], [4], [2].

Nepaisant daugelio jautrumo analizès metodo privalumu, jis turi ir kai kurių trūkumų. Vienas iš ju yra tai, kad ịvertinama tik vieno veiksnio pokyčio įtaka projektui, todèl nèra įvertinami galimi ryšiai tarp atskirų veiksnių, t. y. nèra atsižvelgiama i jų koreliaciją.

Scenarijų analizes metodu galima išvengti minètu jautrumo analizès trūkumų, kadangi jis kartu apima kelių projekto veiksniu, tikrinant jų rizikingumą, pokyčiy ịvertinimą per kiekvieno galimo scenarijaus atsiradimo tikimybę. Be to, parametru pokyčiai įvertinami, atsižvelgiant $i$ jų tarpusavio priklausomybę (koreliacija).

Rizikos analizės technika, kuria ivvertinama projekto, grynosios dabartinès vertès jautrumo priklausomybẻ nuo kritinių kintamujų ir nuo ju pasiskirstymo funkcijos, vadinama scenarijų analizės metodu [4].

Scenarijumi gali būti bet koks pakankamai tikètinas îvykis ar büklè, kurie gali labai paveikti keletą projekto parametrų vienu metu. Šiuo metodu yra ịvertinamas projekto pelningumas kiekvieno scenarijaus atveju ir pagal kiekvieną iš ju yra nusakoma ivvykių eigos tikimybè.

Reikia pažymèti, kad scenarijų metodą efektyviai galima taikyti tik tada, kai galimu grynosios dabartinès vertės reikšmių skaičius yra ribotas.

Kadangi ịvertinant projektą dažniausiai susiduriama su begaliniu scenariju skaičiumi, projekto rizikai ivertinti pasitelkiamas imitacinis modeliavimas. Šio metodo pagrindą sudaro tikimybinis ịvairiu aplinkybiu atsiradimo ịvertinimas. 
Paprastesni rizikos ịvertinimą taikant imitacini modelį pateiké J. S. Melkumovas [8]. Pagal šị metodą pirmiausia, remiantis ekspertiniais vertinimais, išskiriamos trys projekto (arba keliu projekty) scenariju eigos galimybès: pesimistiné, realistinè ir optimistinè. Kiekvienam variantuji apskaičiuojama grynoji dabartinè verte $(N P V)$. Po to apskaičiuojamas kiekvieno projekto $N P V$ variavimo diapazonas $\left(R_{N I V}\right)$ :

$$
R_{N P V}=N P V_{O}-N P V_{P},
$$

kur $N P V_{O}$ - optimistinio varianto $N P V, N P V_{P}-$ pesimistinio varianto NPV. Arba galima apskaičiuoti vidutinį kvadratinị nuokrypị pagal formulę:

$$
\sigma_{N P V}=\sqrt{\sum_{1}^{3}\left(N P V_{i}-\overline{N P V^{2}} \times P_{i}\right)},
$$

kur $N P V_{i}$ - kiekvieno nagrinejamo varianto grynoji dabartinè verté.

$N P V$ - vidutiné $N P V$ reikšmé, pasverta pagal nurodytas tikimybių reikšmes $\left(P_{i}\right)$ :

$$
\overline{N P V}=\sum_{1}^{3} N P V_{i} P_{i} .
$$

Rizikingesnis bus tas projektas, kurio variavimo diapazonas arba vidutinis kvadratinis nuokrypis yra didesnis.

Sprendimy medis paprastai sudaromas tuo atveju, jeigu rizikos analizè atliekama keliems projektams (arba vieno projekto keliems variantams), kurie turi gana didelį eigos variantụ kiekị, arba jeigu lěšu investavimas i projektą trunka keletą metu, t.y. projektas igyvendinamas daugiapakopiškai.

Projekto analitikas, sudarydamas sprendimu medi, turi tureti pakankamai informacijos ne tik apie galimus projekto eigos variantus, bet ir apie ju atsiradimo momentus bei ju tikimybę.

Remiantis surinktais duomenimis, sudaromas sprendimu medis, kuriame mazgai atitinka svarbiausius ịvykius, o linijos, jungiančios tuos mazgus, projekto realizavimo darbus. Be to, šio medžio schemoje užrašoma ir informacija apie vieno ar kito sprendimo priemimo laiką, jo darbu vertę ir sprendimo prièmimo tikimybę. Galiausiai apskaičiuojama kiekvieno galimo scenarijaus grynoji dabartinè vertè ir integralinè jos reikšmè.

Vienas iš formalizuotų neapibrěžtumo aprašymo metodų, taikomų ypač sudètinguose prognozavimo atžvilgiu projektuose, yra Monte-Karlo imitacinio modeliavimo metodas. Šis metodas - tai dviejų meto$d u-$ jautrumo analizès ir scenariju analizès, pagristos tikimybių teorija, - integracija. Atlikus šią kompleksinę analizę, gaunami tikimybiniai galimų projekto rezultatu pasiskirstymai. Rizikos analizès pagal Monte-Karlo metodą schema pateikta 1 pav. Ji sudaryta remiantis keliais literatūros šaltiniais [4], [2], [6].

Paskutiniame šio metodo etape yra atliekama imitacinio modeliavimo rezultaty analizè. Svarbiausias sprendimo priemimo kriterijus yra tokio projekto parinkimas, kurio grynosios dabartinès vertès tikimybinis pasiskirstymas labiausiai atitinka konkretaus investuotojo požiūrị i riziką. Be grynosios dabartinès vertès tikimybinių charakteristikų, dar gali būti nustatyti ir tokie rodikliai: laukiami nuostoliai $N$ iš projekto (t. y. visų neigiamų rezultatų, padaugintų iš jụ pasirodymo (atsiradimo) tikimybès, suma); laukiamos pajamos $\mathrm{P}$ iš projekto (t. y. visu teigiamy rezultatu, padaugintụ iš ju pasirodymo tikimybès, suma). Remiantis šiais rodikliais gali būti apskaičiuota neapibrèžtumo verté investuotojui: jeigu projektas bus priimtas, ji lygi $N$, jeigu atmestas, $-P$.

Ivertinant projekto rizikos lygi, kurio teigiamų ir neigiamų rezultatu gavimo tikimybės yra panašios, yra taikomas laukiamų nuostolių koeficientas [2]:

$$
K_{N}=N /(N+P) \text {. }
$$

Bendru atveju laukiamas integralinis efektas gali būti apskaičiuojamas pagal formulę:

$$
E_{L}=\lambda \times E_{\text {max }}+(1-\lambda) \times E_{\text {min }},
$$

kur $E_{\text {max }}$ ir $E_{\text {min }}$ - didžiausia ir mažiausia iš integralinio efekto matematiniu vilčiu pagal leistinus tikimybinius pasiskirstymus; $\lambda$ - specialus normatyvas neapibrěžtumo efektui ivertinti, kuris parodo ūkinio subjekto teikiamy pirmenybiu (prioritetų) sistemą neapibrežtumo sąlygomis.

Paprastai, îvertinant laukiamą integralinį ekonomini efektą, rekomenduojama šio normatyvo reikšmè lygi 0,3 [2].

Kaip jau buvo minèta, analizuojant projekto riziką, labai svarbi yra rizikos valdymo sąvoka, kuri apima tiek rizikos ir neapibrežtumo veiksnių identifikavimą ir îvertinimą, tiek ir rizikos ịtakos projekto efektyvumui sumažinimo metodus ir būdus. 
Išanalizavus keletą literatūros šaltinių [2], [4], [5], darbe pateiktas pakoreguotas ir pritaikytas statybos investiciniams projektams rizikos valdymo modelis (2 pav.).

Beje, reikia pabrežti, kad analizuojant verslo projekto rizikingumą netikslinga atskirti rizikos analizés ir rizikos bei neapibrèžtumo sumažinimo metody, kadangi galutinis analizès tikslas ir yra priemonių ir būdų, igalinančių sumažinti projekto rizikingumą, nustatymas. Tačiau, norint igyvendinti kokią nors riziką sumažinančią priemonę (draudimas, rizikos diversifikacija, dalinių rizikų neutralizavimas, rizikos sumažinimas finansy planavimu, papildomy ištekliu sukaupimas), reikia pirmiausia atlikti rizikos analizę.

Kitaip sakant, reikia sukurti sistemą, i kurią ieity visi organizaciniai ir ekonominiai stabilizaciniai mechanizmai, kuriems reikia papildomy sąnaudu ir kuriy apimtis priklauso nuo projekto realizavimo sąlygų, dalyvaujančiųų projekte lūkesčiu ir tikslų bei ivertinto galimos rizikos laipsnio.

\section{Prognozių modelis}

Modelio, galinčio prognozuoti būsimą realybę, parengimas. Kaip pagrindas imamos matematinès priklausomybès, gautos apskaičiavus projekto efektyvumo rodiklius (pvz., NPV).

\section{Rizikos kintamieji}

Pagrindiniu projekto kintamujjų atrinkimas. Siame etape naudojami jautrumo analizès rezultatai.

\section{Tikimybinis pasiskirstymas}

1-as žingsnis: galimų kintamujjy reikšmiu (minimalių ir maksimaliu) apribojimy nustatymas.

2-as žingsnis: tikimybiniu svertų pagal reikšmių ribas paskirstymas. Kitaip sakant, prognozuojama tikimybinio pasiskirstymo, neviršijant numatytu ribų, rūšis ir parametrai.

\section{Koreliacijos sqlygos}

Koreliuojančiu kintamuju santykių nustatymas. Matematinès statistikos metodais (arba ekspertiniais metodais) nustatomas koreliacijos koeficientas tarp kiekvienos priklausomos kintamuju poros.

\section{Imitacinès prognozès}

Atsitiktinių scenarijų, pagrịstų pasirinktomis prielaidomis, generavimas. (Čia reikia prognoziu modelio, parengto kompiuteriu.)

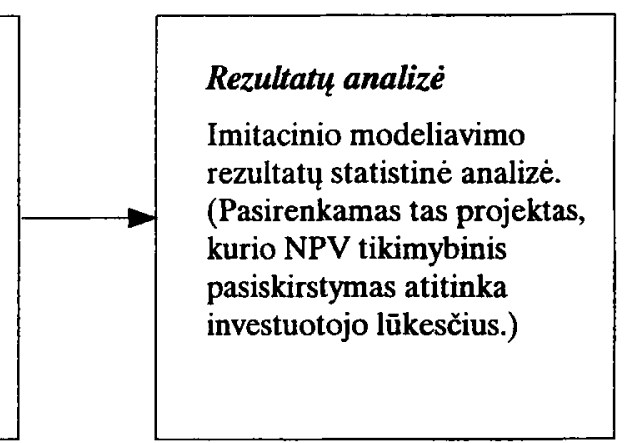

1 pav. Rizikos analizès pagal Monte-Karlo metodą schema

Fig 1. Risk analysis according to Monte-Carlo technique 


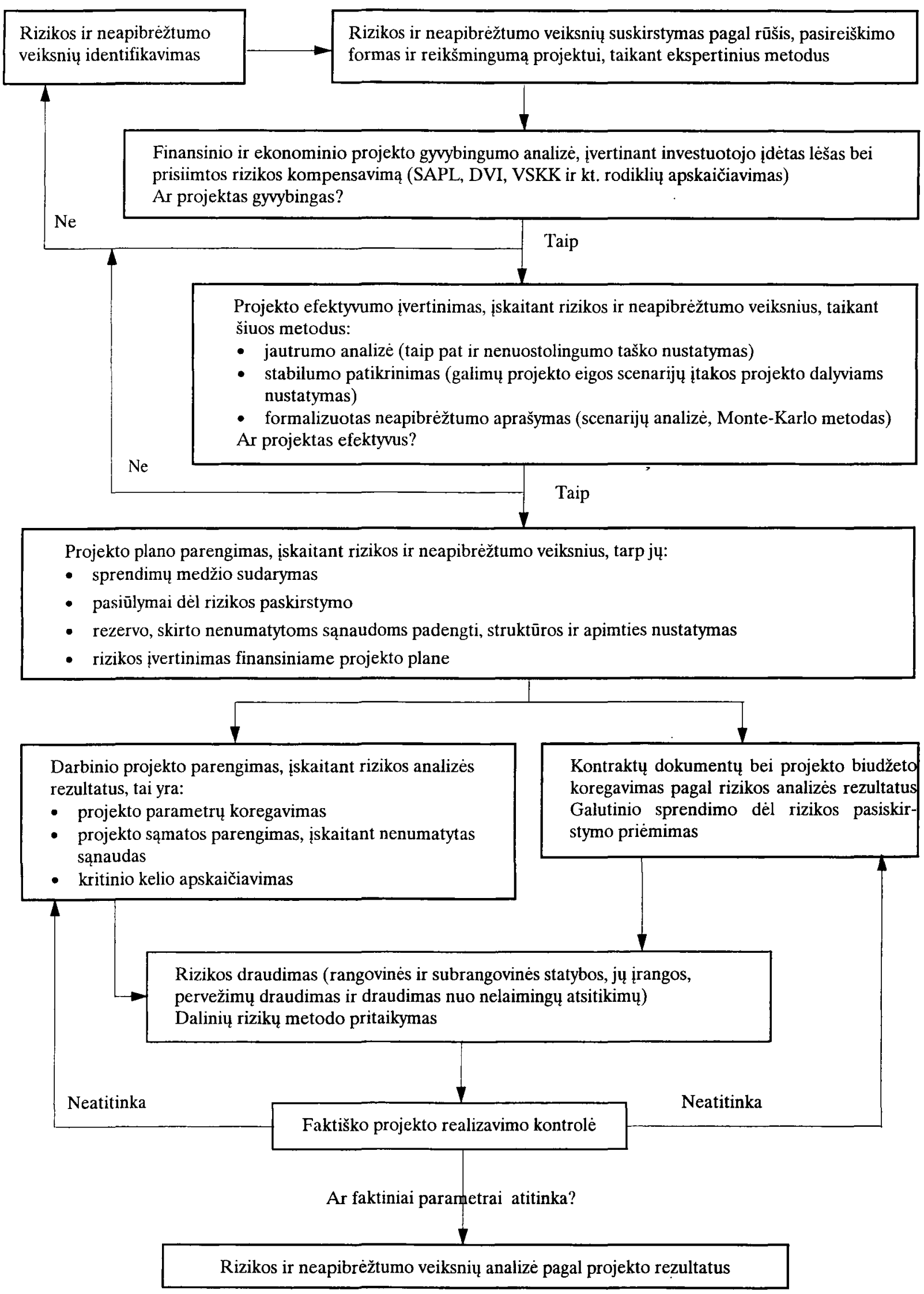

2 pav. Rizikos valdymo modelis

Fig 2. Model of risk management 


\section{Išvados}

1. Praktiškai neįmanoma išvengti nepakankamos arba netikslios informacijos apie projekto realizavimo sąlygas, dèl ko gali atsirasti nepalankios situacijos ir ju pasekmès. Todèl būtinas darbų, atliekamų visame projekto gyvavimo cikle, komponentas yra rizikos ir neapibréžtumo analizè. Darbe pateikta keleto autoriu rizikos ir neapibrèžtumo analizès schemu apžvalga ir pasiūlyta schema, adekvačiai tinkanti investiciniams statybos projektams.

2. Rizikos analizès būtinumą lemia ir tai, kad bet kokio investicinio projekto sudaryti pinigu srautai priklauso büsimiems periodams ir yra prognostinio pobūdžio. Taip dar labiau padidejja skaičiavimams naudojamų duomeny nepatikimumas. Straipsnyje išnagrinėtas ịvairaus pobūdžio rizikos analizės metody tinkamumas investiciniams statybos projektams.

3. Rizikos analizès rezultatais naudojasi visi projekto dalyviai - užsakovai (investuotojai), projektavimo firmos, rangovai, bankai, draudimo kompanijos. Todèl rizikos rezultaty patikimumas - svarbiausias veiksnys visų projekto dalyvių tolesnès veiklos rezultatams.

4. Sukurtos specialios metodikos ir būdai, kuriuos taikant galima atrinkti ir pagal svarbumą ivertinti rizikos veiksnius bei sukurti projekto realizavimo proceso modeli, ịvertinantị nepalankių pasekmiu ịvykimo galimybès tikimybes bei parenkantị nepalankių pasekmiu sumažinimo metodus. Šị metodų visumą priimta vadinti rizikos valdymu. Darbe pateiktas pakoreguotas ir pritaikytas investiciniams statybos projektams rizikos valdymo modelis.

5. Rizikos analizès dèka galima koreguoti sprendimus dèl nepakankamai pelningu projektu. Pavyzdžiui, projektas, kurio grynoji dabartinè vertè yra nedidelè, gali būti priimtas, jeigu rizikos analizès metu išaiškès, kad patenkinamy pajamų gavimo tikimybė yra didesné nei nepriimtiny nuostoliy tikimybè. Straipsnyje išnagrinéti šios problemos savitumai investiciniams statybos projektams.

\section{Literatūra}

1. R. Tamošiūnienè. Rizikos tipai ir jos valdymo metodai verslo projektavime // Respublikinès mokslinès konferencijos "Lietuvos ükio reformos", îvykusios Klaipèdoje $1997 \mathrm{~m}$. rugsejjo 25-26 d., medžiaga. Klaipèda: KU leidykla, 1997, p. 204-207.
2. В. Д. Шапиро и др. Управление проектами. Санкт-Петербург: Два-трИ, 1996. 610 с.

3. Л. И. Лопатников. Экономико-математический словарь / Словарь современной экономической науки. Издание 4-ое, переработанное и дополненное. М.: Изд-во “АВF”, 1996. 704 с.

4. И. М. Волков, М. В. Грачева. Проектный анализ: Учебник для вузов. Банки и биржи, ЮНИТИ, 1998. $423 \mathrm{c}$.

5. В. 3. Черняк. Управление инвестиционным проектом в строительстве. М.: Русская деловая литература, $1998.800 \mathrm{c}$.

6. М. Эддоус, Р. Стенсфилд. Методы принятия решений / Пер. с англ. Под ред. член-кор. РАН И. И. Елисеевой. М.: Аудит, ЮНИТИ, 1997. $590 \mathrm{c}$.

7. W. Behrens, P. M. Hawranek. Manual for the Preparation of Industrial Feasibility studies. Vienna: UNIDO Publication, 1991. 385 p.

8. Я. С. Мелкумов. Экономическая оценка эффективности инвестиций и финансирование инвестиционных проектов. М.: ИКЦ “ДИС”, 1997. $160 \mathrm{c}$.

Itteikta 19981203

\section{RISK ANALYSIS IN THE INVESTMENTS OF CONSTRUCTION PROJECTS}

\section{R. Tamošiūnienè}

\section{Summary}

Lithuanian economy transformation into a market economy extremely increased the risk of enterprises. Transition from a producer market to a consumer market caused the technological innovations in construction business. It needs long-term investments. So the management of such investments risk is a problem of today.

The paper deals with indentifying conceptual problems of risk and uncertainty definition as well as indicators for the quantitative risk management.

Some aspects of the application of the risk management ideology which is thought as risk analysis and risk reduction are discussed. Risk analysis includes methods such as sensitivity analysis, breakeven point analysis, mathematical programming methods, scenario analysis, Monte-Carlo technique etc.

There are many types of risk in business. Risks can be classified as external unforeseeable risks, external foreseeable (but not determined) risks, operating risks, technical risks, legal risks etc. The first step in risk management is the risk analysis, then follows the application of risk reduction methods.

Rima TAMOSIUUNIENÉ. Assistant. Business Management Faculty. Vilnius Gediminas Technical University (VGTU), Saulètekio al. 11, 2040 Vilnius, Lithuania.

A graduate of VGTU Building Economy and Organization Faculty (1987). Doctoral student (1993-98). Research interests: project management, mathematics of finance. 